\title{
Improving Students English Vocabulary Using Kahoot!
}

\author{
Ayumi ${ }^{1, *} \mathrm{Al}$ Maghvirah Chan ${ }^{2}$ \\ ${ }^{1}$ English Department, Universitas Andalas, Padang, Indonesia \\ ${ }^{2}$ English Department, Universitas Andalas, Padang, Indonesia \\ ${ }^{*}$ Corresponding author. Email: ayumi@hum.unand.ac.id
}

\begin{abstract}
Acquiring vocabulary is compulsory for students to apply them later in their university year when writing their thesis. The combination of traditional and interactive to enhance student's vocabulary can show a significant result. This article aims to see how Kahoot! contributes to students' vocabulary improvement in the Intermediate Reading and Writing class.
\end{abstract}

Keywords: Vocabulary learning, Kahoot!, English vocabulary

\section{INTRODUCTION}

Acquiring vocabulary for a language learner is essential in mastering the language itself. Words are what build a language[1]. They are what we need to understand the language. Not knowing the words will make it impossible for us to communicate in the desired language.

Globalization has attracted people to learn the English language. Aside from being the most widely spoken language globally, the interest in the global trade, scientific resources available in English, interest in literature, and broader opportunity in finding jobs are some of the other reasons responsible for the worldwide appeal in learning the language.

Learning a second language requires frequent practices and sustained efforts. It involves four necessary skills, listening, speaking, reading, and writing. Listening and speaking relate to real oral communication while reading and writing deals with the written form of it[2]. All these four skills involve vocabulary. Nowadays, in many coursebooks of language learning, the publisher often emphasizes the wide range of vocabulary introduced in the books[3].

Vocabulary proficiency is one of the aspects of learning a foreign language[4]. Students will not be able to understand what they are hearing or reading without knowing the vocabulary. They will not be able to speak or write in the target language without them also. In other words, vocabulary proficiency relates to language proficiency [5][6]. For a language learner, to achieve the desired command in a foreign language is a complex and challenging endeavors [7].

According to [1] [4], students' knowledge of vocabulary involves two main processes; explicit and incidental learning. They suggest that explicit learning is through deliberate and focused techniques, while the latter focuses on meaning and use. Explicit learning can be through some of these activities, such as guessing meaning from context, speed reading, vocabulary- focused comprehension questions, writing with feedback, computer-mediated written interaction, and writing. Incidental learning can come from extensive listening, where students expose themselves to new vocabulary when they listen to the news, tv programs, podcasts, and movies[1].

The advanced technology in language teaching makes the teaching and learning activities much more exciting and challenging at the same time. The existence of online application makes it easier for teachers to create interactive material for their students. Teachers can make learning activities more enjoyable and exciting. They can create games or quizzes and make it competitive with a leaderboard. Students compete with their classmates in answering the question. This article discusses using an online application Kahoots in improving Intermediate Reading and Writing students' vocabulary.

The Intermediate Reading and Writing course is one of the compulsory courses in semester II at the Department of English Literature, Faculty of Humanities, UniversitasAndalas. This course is an advanced course after the Elementary Reading and Writing course. While in the Elementary Reading and Writing course, students can understand detailed information from a text, and students write a wellstructured paragraph, the Intermediate Reading and Writing students can understand the writers' messages and goals. Students are capable of developing ideas in essay form. As a subject that weighs four credits, meetings are held two times a week. Each meeting has a different focus, namely reading (reading) and writing (writing). The research focused only on meetings for writing sessions.

\subsection{Games in Language Learning}

The use of games in education has long been part of the teaching strategies. Games are playful. A game uses a set of rules which every participant must follow to 
reach the objectives[8]. In education, games function as support tools to engage students in a particular learning objective. They encourage students to develop critical thinking in solving the problems presented in the game [9]. Using games in learning activities can keep students motivated, engaged, and concentrated over time [10].

In vocabulary learning, using games can give students the context of real usage of the words. For example, when teaching students words related to appearance, the Who am I? game has an objective to practice the language of physical description - hair, build, and clothes. In this game, students play in pairs. The teacher gives each student an envelope with a set of picture cards in it. Student A then picks a picture from their collection without showing it to student B and pretend to be the person. Student B needs to guess who they are by asking questions. Student B can ask, Are you a female? If student A says yes, student B must put aside all-male pictures in their set. They then ask, Have you got dark hair? If student A says no, they again need to put all dark-haired women pictures in their set aside. When student A manages to describe student $\mathrm{A}$ and then match their pictures, student $\mathrm{A}$ takes the turn to guess who student B is[11]. This game lets the students experience the learning activity. They engage themselves in using the expressions over and over.

With digital technology so advanced and broad nowadays, it influences education from all aspects, including language learning[7][8][10]. Language learning becomes easy to access because there are abundant resources on the internet, starting from preschool to higher education and professionals. The internet provides many easy to use resources where teachers can create an activity or use the one available for their students. On the other hand, learners can practice both inside and outside the classroom.

\subsection{Kahoot! Inside and Outside the Classroom}

Students may lose their focus, concentration, and motivation during class, which leads to a decrease in learning outcomes. To avoid this, teachers need to provide engaging activities to retain their attention and participation in the lesson. Using game-based learning is a way to keep students engage in learning[10].

Kahoot! is an online quiz platform. It is a gamebased learning platform that adopts the multiple questions format. Kahoot! enables users to use the existing quizzes or create their own and share it[12]. The game is best played in groups, though a user can play the game individually against other people from all over the world.

Since it was first launched in 2013, Kahoot! has been adopted into classroom activity by more than 6 million teachers worldwide and played by 4.4 billion players[13]. Kahoot! can incite high interest and engagement on the participant, improve students' performance that results in the desired learning outcomes[10][14][16][17]. The competitiveness of the application creates a lively learning environment.

Using this application inside or outside the classroom is easy and free. A teacher must first register for an account. They can choose the type of account

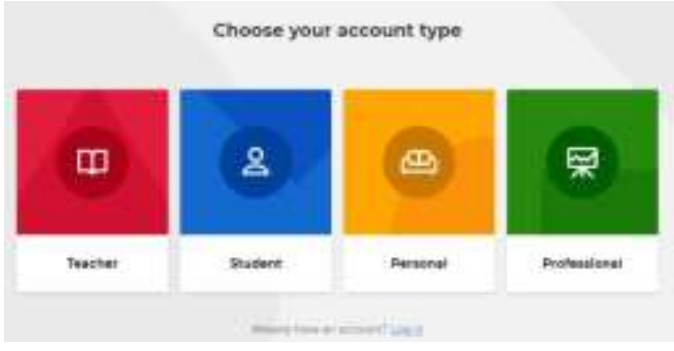

Figure 1. Kahoot! account types

they wish to create. Once registered, a teacher can browse millions of free games available for the public to use. Teachers can also create games that suit their needs.

A teacher can create the games by adding questions, images, or a YouTube link. Kahoot! allows users to import prepared questions in excel form, with the maximum number of items accepted for each game is 100 questions. For each question, a teacher can set the timer for the players to answers. The timer available is up to 240 seconds.

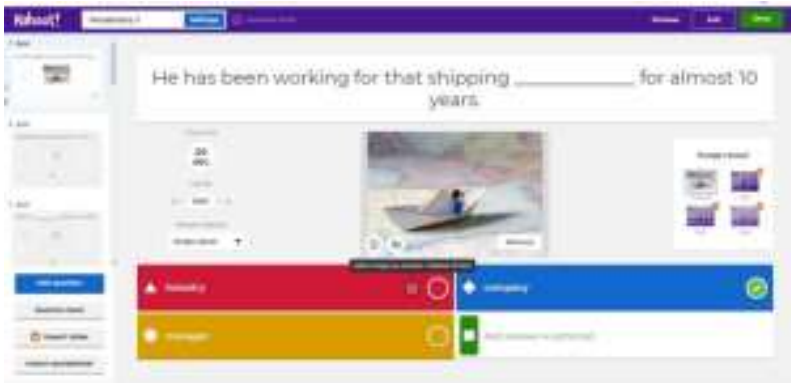

Figure 2. Kahoot! create / edit question page

Once the questions are ready, teachers can set it as an activity in the classroom. The teacher needs to launch the game and choose how the game will be played, 1:1 classic or team vs. team mode. The 1:1 mode is for one device, one player. This mode is suitable if the teacher wants to assess individual students. In a condition where not all students are available with a device, the teacher can use the team mode. On the display screen, students will be able to see the game pin. To join the game, students can use their mobile devices or a laptop. They can either play on the browser or using the Kahoot! App. If they choose to play on the browser, they need to go to https://kahoot.it/ and enter the game pin. Each student who enters the game will appear on the game screen. 
The questions will show up on the screen, and students can choose their answers by pressing the corresponding color or shape of the correct answer on their device. The game will automatically award the right answer based on who is the quickest. The quicker the students answer the question, the higher the score will be. For each question, there will be a leaderboard that shows who is in the lead. The class usually erupts in excitement every time the leaderboard shows up.

\section{METHOD}

The research conducted is a classroom action research that applies suitable intervention to collect and analyze data to implement actions to address teaching methods to improve students' vocabulary[18]. The research participants are students in the Intermediate Reading and Writing class in the 2019-2020 academic year. There were only 11 students registered for the course. In collecting the data, the class implemented the regular activity presented in the main coursebook for the first half of the semester. The purpose is to compare the students' scores on the vocabulary sections before implementing Kahoot! in the learning activities and after. At the beginning of the semester, students did a pre-test to identify the meaning of 100 words. Before the semester ended, students did the post-test and filled in a survey to see their response to Kahoot!.

Every meeting during the first half of the semester, students did the activity presented in the coursebook without Kahoot!. After the mid-semester test, students did some exercises on Kahoot!. Due to the Covid-19 pandemic, in-person classes after the mid-semester test were switched to online classrooms. Kahoot! online classroom activities were conducted via the Zoom Meeting.

\section{RESULT AND DISCUSSION}

The use of Kahoot! in classroom activity related to vocabulary activities shows an increase in students' performance when identifying meaning from context. Students' vocabulary section score at the end of the semester increases by $18 \%$ from mid-semester. Figure 3 shows that all 11 students pick an increase in score. One student shows a $26 \%$ increase after using Kahoot! for six weeks.

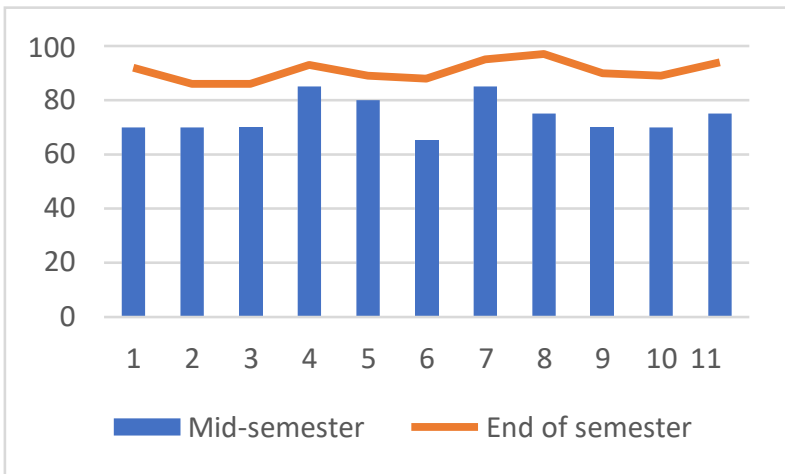

Figure 4 Students' vocabulary score

Students' engagement with Kahoot! also occurs outside the classroom. The chart in Figure 4 shows that $63,6 \%$ of students play Kahoot! whenever they want to. It explains that even without an assignment from the teacher, students enjoy playing it. $27,3 \%$ of them also play it whenever their friends send a challenge, and $18,2 \%$ spend time on Kahoot! to learn which implies that student has the willingness to seek Kahoot! to improve their knowledge.

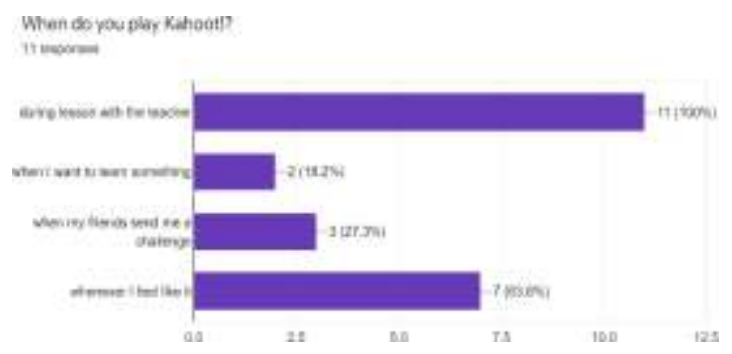

Concerning Kahoot! contribution to students' improvement in learning vocabulary, $72,7 \%$ strongly

Figure 3 Student activity on Kahoot!

agree that it helps them. It is consistent with the increase of scores in vocabulary learning.

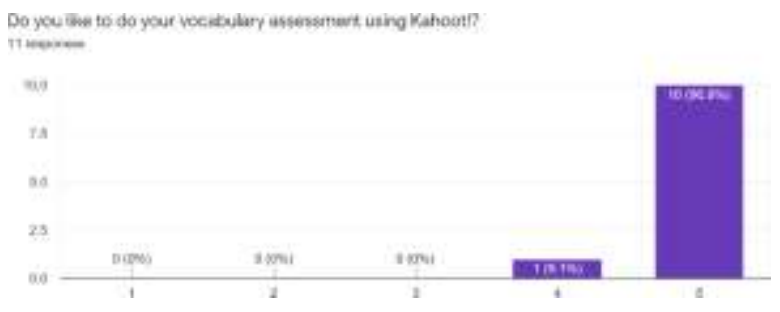

Figure 5 Students' reception to doing classroom activity on Kahoot!

About whether they enjoy doing their vocabulary activity on Kahoot!, as shown in Figure 5, the majority of them strongly agree that they like it. The reason for this can be seen in Figure 6, where 10 out of 11 students 
find that it is not hard to use Kahoot!. They strongly agree that Kahoot! is easy to use.

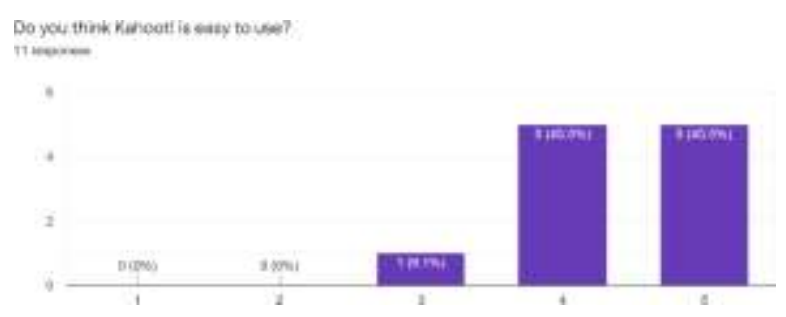

Figure 6 Students' response to Kahoot! user interface

Students also acknowledge that the application increases their learning performance - the concept of learning while playing increases their classroom activity engagement. As much as $81,8 \%$ strongly agree that their attention and interest in the lesson improve because of Kahoot!.

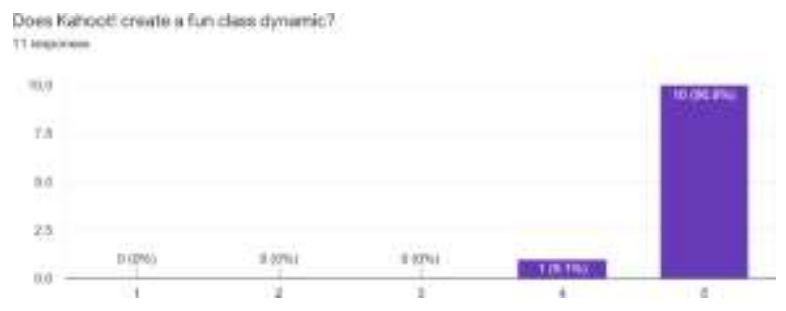

Figure 7 Class dynamics

In terms of class dynamics, students feel that Kahoot! creates fun class dynamics, as in Figure 7. The response gives a picture that integrating Kahoot! in learning activity makes the class excited. Students reacted in excitement whenever they manage to take the lead on the leaderboard.

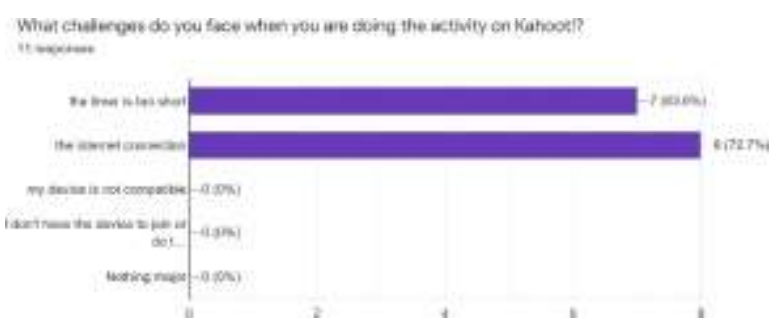

Figure 8 Challenges in using Kahoot!

Aside from all the excitement and fun, students also face challenges every time they are on Kahoot!. Connection problems yield on top with $72,7 \%$, and short timing for the students in answering the questions come second. There are no students in the Intermediate
Reading and Writing class with problems with device compatibility and availability.

\section{CONCLUSION}

Research results show that technology can be useful in language learning so that learning becomes exciting and fun. Kahoot! has a positive effect on student activities in the classroom. They play an active role to be involved in answering the questions. Learning using applications makes the teaching and learning process interactive. The students compete with each other to answer the questions as quickly as they can. Student answers that appear on the screen.

Furthermore, the use of this application makes the classroom atmosphere come alive. Students raise and cheer if they get the answer right. They feel disappointed when they give a wrong answer, and they clap their hands after knowing the winner of the game that appears on the monitor screen. Their enthusiasm to play Kahoot! every time they come to class shows that Kahoot! is considered fun and enjoyable. Students can play Kahoot! not only in the classroom but also outside the classroom.

\section{ACKNOWLEDGMENT}

LP3M Universitas Andalas funds this research.

\section{REFERENCES}

[1] S. Webb and P. Nation, How vocabulary is learned, United Kingdom: Oxford, 2017.

[2] L. M. Sadiku, "The Importance of Four Skills Reading, Speaking, Writing, Listening in a Lesson Hour," European Journal of Language and Literature Studies, vol. 1, no. 1, pp. 29-31, 2015.

[3] S. Thornbury, How to teach Vocabulary, Oxford: Pearson Education Limited, 2002.

[4] A. Burns and H. de Silvia Joyce, Eds., Teacher's voices 7: Teaching vocabulary, Sidney: Macquarie University, 2001.

[5] F. F. Y. T1lfarlığlu and Y. Bozgeyik, "The Relationship between Vocabulary Learning Strategies and Vocabulary Proficiency of English Language Learners," International Journal of Applied Linguistics \& English Literature, vol. 1, no. 2, pp. 91-101, 2012.

[6] T. S. Paribakht and S. Webb, "The 
relationship between academic vocabulary coverage and scores on a standardized English proficiency test," Journal of English for Academic Purposes, vol. 21, pp. 121-132, 2015.

[7] R. Al-Mahrooq and S. Troudi, Using Technology in Foreign Language Teaching, R. Al-Mahrooq and S. Troudi, Eds., United Kingdom: Cambridge Scholar Publishing, 2014.

[8] C. Perrotta, G. Featherstone, H. Aston and E. Houghton, "Game-based Learning: Latest Evidence and Future Directions." NFER, Slough, 2013.

[9] V. S. Zirawaga, A. I. Olusanya and T. Maduku, "Gaming in Education: Using Games as a Support Tool to Teach History," Journal of Education and Practice, vol. 8, no. 15, pp. 55-64, 2017.

[10] A. I. Wang and R. Tahir, "The effect of using Kahoot! for learning - A literature review," Computers \& Education, no. 149, 2020.

[11] F. O'Dell and K. Head, Games for vocabulary practice, Cambridge University Press, 2003.

[12] Kahoot!, "Kahoot!,” 2020. [Online]. Available: https://kahoot.com/what-iskahoot/.

[13] Kahoot!, [Online]. Available: https://kahoot.com/company/. [Accessed September 2020].

[14] S. Felszeghy, S. Pasonen-Seppänen, A. Koskela, P. Nieminen, K. Härkönen, K. M. A. Paldanius, S. Gabbouj, K. Ketola and M. Hiltunen, "Using online game-based platforms to improve student performance and engagement in histology teaching," $B M C$ Medical Education, 2019.

[15] P. Bawa, "Using Kahoot to Inspire," Journal of Educational Technology Systems, vol. 0, no. 0, pp. 1-18, 2018.

[16] H. S. ÇETIN, "Implementation of the Digital Assessment Tool 'Kahoot!' in Elementary School," International Technology and Education Journal, vol. 2, no. 1, 2018.

[17] C. M. Plump and J. LaRosa, "Using Kahoot! in the Classroom to Create Engagement and Active Learning: A Game-Based Technology Solution for eLearning Novices," Management Teaching Review, 2017.

[18] D. R. Tomal, Action research for educators, Rowman \& Littlefield Education, 2010. 